\title{
Technical Vocational Education and Training (TVET) Workforce Skill Development Policy and Strategy to Support 4th Industrial Revolution due to Disruptive Technology
}

\author{
Pongpith Tuenpusa ${ }^{1,2^{*}}$, Somsak Boonpoo ${ }^{2}$, Peravat Chaisuk ${ }^{2}$ \\ ${ }^{1}$ Rajamangala University of Technology Thanyaburi, Pathum Thani, Thailand \\ ${ }^{2}$ Faculty of Education, Mahachulalongkornrajavidtayalai University, Ayutthaya, Thailand \\ Email: * pongpith@rmutt.ac.th, pchaisuk@gmail.com, boonpoo999@hotmail.com
}

How to cite this paper: Tuenpusa, P., Boonpoo, S., \& Chaisuk, P. (2021). Technical Vocational Education and Training (TVET) Workforce Skill Development Policy and Strategy to Support 4th Industrial Revolution due to Disruptive Technology. Journal of Human Resource and Sustainability Studies, 9, 596-607.

https://doi.org/10.4236/jhrss.2021.94037

Received: October 22, 2021

Accepted: December 12, 2021

Published: December 15, 2021

Copyright $\odot 2021$ by author(s) and Scientific Research Publishing Inc. This work is licensed under the Creative Commons Attribution International License (CC BY 4.0).

http://creativecommons.org/licenses/by/4.0/ (c) (i) Open Access

\section{Abstract}

Research papers on Technical Vocational Education and Training Workforce Skill Development Policy and Strategy to Support fourth industrial revolution due to Disruptive Technology aim to explore directions, trends, impacts, as well as policies for managing labor issues in the Disruptive Technologies era, studying the opinions of executives of businesses used or affected by Disruptive Technology, as well as obstacles, feedback, focusing on issues, concepts about Disruptive Technologies and vocational education concepts. Research methodology used in qualitative research and procedures for conducting studies. The study results are the impact of Disruptive Technology on Thai workers and technical vocational education and training (TVET) to develop a skill for the Thai workforce during disruptive technology, educational management to develop Thai people in the Thai era.4.0. Therefore, two focuses must be placed on: 1) increasing labor skills and 2) educating new workers under reality. In conclusion, the article outlines the approach of skill development to the labor force that must be advanced in the era of Disruptive Technology. It was briefly explained that realistic work means workers with flexible knowledge and skills adapting to advanced technologies. Therefore, for work to meet the required standards, TVET development requires a professional standardization process, namely information related to work knowledge. Creating the necessary skills and attributes requires operational standards. Procedures and scope of operation operational equipment prove performance and expertise in technical skills knowledge, competence, and performance results and policy recommendations on the government sector: Private Educational Institutions in managing labor issues in the Disruptive Technology era.
\end{abstract}




\section{Keywords}

Disruptive Technology, TVET, Vocational Education, Workforce Skill

\section{Introduction}

The OECD (2018) estimates that over the next 15 years, $14 \%$ of workers are at high risk of being replaced by automation, and another $30 \%$ face significant changes in the skills used in the workforce. Many countries worldwide have struggled to create young people and working-class people with work skills and life skills high enough for disruptive technology. Linked to changes in work and employment, Disruptive Technology is a term that describes the large-scale changes that have occurred from modern technology of robotics and automation (Hynes, Elwell, \& Zolkiewski, 2016). It will have an immediate and severe impact on careers and work skills, a crucial part of the fourth industrial revolution.

In Joseph Bower and Clayton Christensen's article "Disruptive technology: catch the wave," he said that some new technologies could destroy or change the order of existing market domination or even create new markets (Bower \& Christensen, 1995). Furthermore, in 1997, Clayton M. Christensen said that the model of technological development, Sustaining Technology, was a gradual improvement. Disruptive technology, a new storm, may initially be incomplete but can improve rapidly and efficiently beyond mainstream technology. Technology forecasters have identified a group of disruptive technology, artificial intelligence, 3D printing, advanced materials, and nanotechnology that create and expand each other, affecting socioeconomic, political, geographic, and population factors (Manyika et al., 2013; World Economic Forum, 2016).

According to the National Economic and Social Development Board, the unemployment rate in the third quarter of 2017 was 450,000 people unemployed, $0.9 \%$ higher than the same period last year. The use of industrial machinery is increasing, but the use of the industry is in line with the government's Thailand 4.0 policy, and the industry needs to use machinery in part because Thailand is moving into an aging society. The proportion of older people now reaches $10 \%$ of the population of 67 million. It will increase to $20 \%$ in the future, so the industry must prepare for production processes in line with working-age people due to lower birth rates.

For Thailand, "Thai People's Development 4.0" is the most critical factor driving the country from middle-income trap countries to high-income countries. The ideal educational arrangement for the development of Thai people 4.0 is TVET education and training, which is recognized worldwide for its role in preparing people to participate in the creation of work values and critical sources of the workforce and skilled workforces, and critical skills in the 21 centuries for TVET learners including: 1) Science, Technology, Engineering, Mathematics (STEM), 2) problem-solving, and 3) 4C's (critical thinking, commu- 
nication, collaboration, and creativity).

This study aims to explore directions, trends, impacts, and policies for managing labor issues in the Disruptive Technologies era, studying the executive's opinions of businesses used or affected by Disruptive Technology, obstacles and feedback, and other issues.

\section{Literature Review}

The concepts and theories involved in this research consist of two parts: 1) concepts about Disruptive Technologies and effects 2) concepts on Technical Vocational Education and Training (TVET).

Concepts about Disruptive Technologies and effects

Disruptive technology refers to innovations or technologies that are used to create markets and value products that apply technology and severely impact the market of existing products, as well as potentially causing businesses that use traditional technologies to be knocked down or closed, unlike conventional innovations that Nama uses for efficiency-enhancing purposes. Increase product quality or reduce traditional route costs only. In its report, the McKinsey Global Institute identified 12 technologies that would influence global change:

1) Mobile Internet is a tool that uses Internet technology to connect with the world, such as mobile banking, which is an Internet financial transaction.

2) Automation of Knowledge Work is a technology or intelligent and intelligent software used to diagnose diseases to achieve accuracy or use in legal analysis.

3) The Internet of Things implants smallest to smallest sensors to transmit communications, which can be used, such as recognizing the quality of the soil from sensors sprinkled in the soil, knowing which crops should be grown with the best yield.

4) Cloud computing is a data storage technology and software integrated to use that enables small businesses to compete with large businesses without investing in a high computer.

5) Advanced robotics technology is used in surgery to minimize patients' impact and accurate surgical outcomes.

6) Autonomous vehicles are technologies that are substituted in agricultural or forestry exploration, as well as military.

7) Next-Generation Genomics is an improved technology that develops genes to treat diseases.

8) Next-generation storage is the creation of Fuel Cells for use in electric vehicles and Highbridge.

9) 3D Printing technology is a $3 \mathrm{D}$ printing system that reduces the cost of production of goods by being used in dental and medical applications.

10) Advanced Materials technology is always the production of new materials such as self-cleaning materials, ultra-strong and light, etc.

11) Advanced Oil-Gas Exploration and Recovery is a technology that ad- 
vances in pioneering oil and gas mining. This makes it more oil and gas.

12) Renewable Electricity Technology: The Technology generates electricity from sources that never end, such as sunlight, wind, waves, hot springs, etc.

\section{Effects of Disruptive Technology}

Christensen and Rayno (2003) classified the technology into two categories: sustaining technologies, a technology-focused on improving the efficiency of products in traditional mechanical systems. The other type of technology is called Disruptive technologies, which develop products/services to have new systems and look cheaper. Disruptive technology may or may not be the latest technology, perhaps an existing one. However, there are changes in specific market elements, such as quality, production process efficiency, cost, or price, making these technologies the right conditions desirable to become popular with the market. The process by which new technologies change the system (disrupt). The same technology is not new, but it has continuously happened since the past. It will happen longer in the future; it may be called creative destruction, which makes the world more efficient creatively. Consumers receive more quality and responsive products. Existing industry leaders often develop products to be more efficient and sustainable along sustaining technology's path. In contrast, Disruptive Technology develops products aimed at changing new-look systems and products, and in the beginning, customers will not have a demand for disruptive technology.

Clayton Christensen explains why big companies cannot adapt to disruptive technology's transformation in Innovator's Dilemma. For the following reasons:

1) The leading company will have to depend on customers and investors since sustaining technology products are products that are in the current flow, which already have customers, so the company aims to meet the needs of customers by developing the products in the direction they want them to (develop products to work better) and to meet the needs of investors because when developed to be better used, they will be better sold at a better price.

2) More profit Disruptive Technology's market usually starts at smaller markets, where these markets can't meet their needs. The growth of major companies has led to the large companies overlooking it.

3) Disruptive technology's market usually starts at new markets with the appearance of new markets. As a result, the big companies are unable to analyze the market because they have re-emerged. Therefore, the big companies do not invest because they are vulnerable.

4) Existing expertise indicates what the company should do and what it should not do, as companies that develop sustaining technology products will already have expertise. As part of Disruptive Technology, the company does not usually specialize, so it chooses to develop products in the direction of Sustaining Technology rather than Disruptive Technology.

5) Technology consistency with market demand Disruptive Technology products occurs in small markets where sustainability products are unresponsive be- 
cause they are small markets. It turns out that sustaining technology is more than necessary, but disruptive technology products are more in line with consumer demand.

Concept about Technical Vocational Education Educational \& Training (TVET)

The relevant concepts and theories in this section include 1) meaning, technical vocational education, educational and training (TVET), and 2) the skills required for TVET in the 21 century as follows: Technical Vocational Education and Training (TVET) is recognized worldwide for its role in preparing people to participate in creating work value and skilled sources of the workforce. According to a 2001 joint publication by the United Nations Educational, Scientific and Cultural Organization (UNESCO) and the International Labour Organization (ILO) on Vocational Education and Technical Studies and Training for the 21 Century, TVET is defined as 1) as an essential component of the ordinary line, 2) prepares people into the profession and the world of work effectively (Uwameiye \& Uddin, 2017). Similarly, Hollander \& Mar (2009) defines TVET as public and private educational institutions in many forms. Formal or informal education is intended to provide all community members with access to this learning path throughout their lives.

From the above definition, TVET aims to eliminate ignorance. Increase knowledge, develop skills, and cultivate the attitudes necessary to enter the profession and advance (Kukoyi, 2009), in line with the concept of Banleng Sornil, et al. (2005), explaining that TVET's goal is to develop people to their full potential. With the environment in mind, Empower people for sustainable development, provide lifelong education, have professional qualifications, manage open and flexible learning. Certified and compared to transfer experience, high priority to vocational education by designating it as a national agenda. Investment reforms have been implemented in line with the development plan. There are benchmarks for indicators in quality management; there is a link between different studies. Continuing education and work Use performance-based learning with the core skills, skills needed for lifestyle. Personnel must have the right qualifications, quality, and qualifications, with continuous improvements for the status of graduates and professional workers to be comparable to other professional fields.

Reeve (2016) wrote an article titled 21st-century skills students need in technical and vocational education and training (TVET 21). Furthermore, develop teaching and learning based on current educational concepts and practices. It also means providing the critical skills needed in the 21 century, critical skills in the 21 century for TVET learners, and guiding how to build these skills in TVET programs, including science, Technology, engineering, mathematics (STEM), problem-solving, and 4C's (critical thinking, communication, collaboration, and creativity), which are consistent with the concepts in Suebpong Prabyai (2017). The necessary 21 skills of technical and vocational education learners in Thail- 
and, the management of technical and vocational education in Thailand. Those involved need to provide students with core knowledge and key skills of the 21 century: 1) STEM skills, 2) problem-solving skills, and 3) 4 C's skills.

\section{Research Methods}

In conducting a study on the Technical Vocational Education and Training workforce skill development policy and strategy to Support the fourth industrial revolution due to Disruptive Technology.

Research Design: The study authors established the qualitative research methodology by formulating the research methodology or methodology introduced in this study. The summary is as follows:

Documentary research: For determining the methodology by using qualitative research processes with documentary research procedures, the study participants initially conducted the study process following the methodology by using qualitative research processes to study and analyze data from documentary research by reviewing relevant concepts, theories, and literature.

In-depth interview: Methodology is defined by using structured interviews as interviews using all the same questions, an open-ended interview, a flexible and open methodology process.

Populations and samples: The target audience is executives who play a role in shaping the country's labor policies. The key informant interview method to be interviewed, explicitly assigning respondents because respondents are targeted to suit the needs of the study participants, who are called "important informants," who are executives who play a role in shaping state policies related to the production and labor. Business units using Disruptive Technology of 26 people in Thailand.

Qualitative information obtained through interview research and documents is analyzed and processed by linking relationships in various factual terms. Both logically and effectively, in which the analysis is released in the manner of depiction, leads to answers in the study and is summarized academically, accompanying the report's writing. To point out the business operator's perspective on the skills needed to spread the associated Disruptive Technologies. In Thailand 4.0 and the skills needed for students, students, labor, technical, vocational education and training (TVET), in Disruptive Technologies, develop policies to prepare future workers for these businesses.

\section{Result and Discussions}

The Industrial 4.0 era results from disruptive technologies transforming traditional global economic mechanisms based on innovation and modern technology add value and revenue to the industries. It is necessary to restructure the workforce to be ready and enhance applying and using modern technology. The study results will focus on disruptive technology's impact on Thai workers and technical career education and training (TVET) to develop Thai people in the 
Disruptive Technology era.

Impact of Disruptive Technology on Thai workers

Disruptive technologies are a technology that is progressive and can change the lifestyle. In its report, the McKinsey Global Institute identified 12 technologies that will influence global change: 1) Wireless Internet 2) Automated Technology in analytics 3) Internet of Things 4) Cloud Computing 5) Robotics technology 6) Drone or semi-driverless vehicles 7) Biotechnology (genomics) 8) Equipment or energy storage systems 9) 3D printing technology 10) SMART material technology 11) Exploration and oil drilling technology 11) Exploration and oil drilling technology 12) Renewable Energy Technology.

Global Institute also estimates that the use of these 12 technologies can have an economic impact. In 2025, the estimate is not just a guess but an in-depth analysis of critical applications and can generate value in many ways, including consumer surplus demand (Consumer surplus), as a result of better products, cheaper, and cleaner environment.

Many research agencies predict the trend towards modern technology, both automations. Ai IoT (Internet of Things) robots are widely used in the production of goods, services, and everyday life, whether to replace or even take over the labor market. The OECD (2018) estimates that over the next 15 years, $14 \%$ of workers are at high risk of being replaced by automation, and $30 \%$ face significant changes in the skills they use. In addition, many countries worldwide have experienced the problem of not creating young people and working-class people with work skills and life skills high enough to face disruptive technology.

According to Tanad Kaewcharoenpaisan's (2017) research, the S Curve 4.0 ecosystem's workforce strategy is 60 percent and 70 percent by 2022. The software, technology, and IT industries will be the biggest hits, second only to Biotechnology and retail, engineering, and construction. The energy industry, gas, oil, petrochemical, and electricity are less affected. The researchers estimated the workforce to be disrupted between 2018 and 2021, estimating the impact on the workforce that requires the provision or restructuring of work skills to support Disruptive Technologies at 50 percent as follows: 1) Modern vehicles are $400,000,2)$ intelligent electronics, 23,177 people, 3) good income group travel and health tourism. 3,079,342 4) Agriculture and biotechnology 1,247,845, 5) Food processing, 1,494,985, and promotion in the new S Curve industry include 6) Robots, 101,482, 7) Aviation and logistics, 103,001, 8) biofuels and biochemistry. 3796 people 9) Digital 11,576 10) Comprehensive Medical Total 6,509,264.

Career Education and Training (TVET) to develop Thai people in disruptive technology

Education management for Thai people development In Thailand 4.0, there must be two emphasizes 1) increasing labor skills and 2) educating to create new workers following reality. Technical Vocational Education and Training (TVET) is recognized worldwide for its role in preparing people to create work value and skilled sources of the workforce. According to a 2001 joint publication by the United Nations Educational, Scientific and Cultural Organization (UNESCO) 
and the International Labour Organization (ILO) on Vocational Education and Technical Studies and Training for the 21 Century, it defines TVET as 1) as an essential component of the ordinary line, 2) as a way to effectively prepare people into the profession and the world of work. Similarly, Hollander \& Mar (2009) defined TVET in many forms as public and private educational institutions. Formal or informal education is intended to provide all community members with access to this learning path throughout their lives.

Reeve (2016) wrote an article titled 21st-century skills students need in technical and vocational education and training (TVET 21). Furthermore, develop teaching and learning based on current educational concepts and practices. It also means providing the critical skills needed in the 21 century, critical skills in the 21 century for TVET learners, and guiding how to build these skills in TVET programs, including science, technology, engineering, mathematics (STEM), problem-solving, and 4C's (critical thinking, communication, collaboration, and creativity), which are consistent with the concepts in Suebpong Prabyai (2017). The necessary 21 skills of technical and vocational education learners in Thailand, the management of technical and vocational education in Thailand. Those involved need to provide students with core knowledge and key skills of the 21 century: 1) STEM skills, 2) problem-solving skills, and 3) 4 C's skills.

STEM Education is an educational approach that integrates knowledge between subjects such as scientific knowledge, technological knowledge, engineering knowledge, and mathematical knowledge. S: Science is a subject on the study of phenomena, in nature, based on the scientific inquiry process. T: Technology is a subject that applies other related fields of work to solve problems. Improve, modify or develop things to meet human needs or necessities. E: Engineering is a subject that is about innovating or creating things to facilitate humans. Based on knowledge of science, mathematics, and technological processes, apply them to create pieces. M: Mathematics is a subject that studies computational or computational subjects that are fundamental to the study and further engineering.

Creative Problem Solving refers to the process of finding answers and solving problems, as well as improving the status quo. Collaboration between creativity and critical thinking Creativity can be done by thinking as profoundly and variedly as possible without judging ideas as good or not, until a certain point considering them with judgment. To choose and evaluate the solution until the best solution is made. Plan solutions and solve problems by believing that they can solve problems and control themselves to solve problems with prudence and completeness. Assemble five steps as follows

Step 1: Accessing problems is to understand, get to know the situation in question. It is carefully studied in detail to identify problems that need to be addressed. Explore data from data sources, the framework for solving the problem.

Step 2: To come up with a solution is to use creativity to find as many solutions as possible. It is not judged whether the idea is wrong or based on the 
amount of thinking necessary for solving the problem, including creating a new solution from the original method.

Step 3: Selecting and preparing is to evaluate the solution with the criteria that are created to the best choice. Then consider the support and potential obstacles in the rescheduling and planning process.

Step 4: Problem planning is problem planning, guaranteeing the feasibility of a solution. Monitor, track, improve the activities used to solve problems. Plan solutions using a person's abilities and limitations Context, conditions, resources, and obstacles, whose steps are 1) Resource evaluation, are identifying the guidelines and resources required to solve problems.

Step 5: Take action: Put the plan into action. Directing and tracking solutions Compared to the result or target set. Problem-solving behavior is observed and recorded. When as planned, it provides self-reinforcement.

4C Skills for innovations are teaching styles that stimulate students' self-learning, which will be the critical skills of people in the 21 century. Critical thinking solves problems. Communication is one of the top skills the new world is looking for. Academic knowledge is essential as a base for in-depth expertise, but cognitive (creative, analytical) and socializing skills with others (working, communicating with others) or 4Cs skills are bridges to the real world of $4 \mathrm{Cs}$ or four areas of learning and innovation skills:

1) Creativity and innovation think outside the box and build on it.

2) Critical Thinking and Problem-Solving think critically and solve problems themselves.

3) Communication communicates properly.

4) Collaboration, collaboration with others.

Summary of Education Management for Thai People Development in Thailand 4.0, there must be two emphases: 1) increasing labor skills and 2) educating to create new workers following reality. Realistic work means workers with flexible knowledge and skills and adapting to advanced technologies. Therefore, for work to meet the required standards, TVET development requires a professional standardization process, namely information related to work knowledge. Creating the necessary skills and attributes requires operational standards. Procedures and scope of operation Operational Equipment Proof of performance and expertise in technical skills knowledge, necessary competence and performance results, etc.

Based on the study results, quantitative analysis Studies based on documents and In-depth Interviews can summarize the skills needed for labor development: 1) STEM skills, 2) problem-solving skills, and 3) 4 C's skills. The results correspond to all the research mentioned above.

\section{Conclusion and Suggestions}

\subsection{Conclusion}

According to interviews with target audiences, executives shape state policies re- 
lated to production and labor. The 26 business entities that operate Disruptive technology concluded that 1) the business agency provides technology workers with the following qualifications to determine the following in time, use technology as language skills, manage data and improve yourself regularly, 2) skills of employees that the sector needs: technology skills, adaptation skills, quick learning skills, emotional intelligence, and 3) ways to improve employee skills: develop to learn, understand and use technology at a basic level, focus on creating an experience for employees by providing training in departments or sending training in educational institutions or training institutions, and bringing talent, digital generations to the organization.

The general policy should support and promote the direction of development: do not discourage fear of disruption; formulate appropriate and flexible policies and regulations; promote the creation of the country's capacity to develop innovation and technology. At the same time, there must be a proactive policy if new technologies change the skill characteristics of the labor market by promoting technical career education and training (TVET) courses at both school and university level, flexible and adaptable. It can increase the learning opportunities of workers at work and throughout life.

\subsection{Suggestion}

Policy recommendations on the part of government and educational institutions for managing labor issues in the Disruptive Technology era.

1) To create a database and utilize the data to manage big data, such as the number of workers that must be produced should be in line with the needs of the labor market in order to achieve maximum efficiency, increase the number of workers and reduce the unemployment of the number of domestic workers.

2) Establish standards, adjust attitudes, perspectives, and change values in Thai society to accept professional skills rather than focus on diplomas, focusing on graduating professions, having a job, or being independent.

3) A clear and concrete national strategy and a plan for developing technology and innovation must be defined, such as Artificial Intelligence: AI, Machine Learning, etc., for both short-term and long-term plans (5 - 10 years) ahead while providing ongoing budget support.

4) It must raise awareness and awareness for people in the country, both in the private sector. The social sector and the general public have focused on the consequences of technology and innovation.

5) Promoting and supporting scholarships in technology and innovation such as basic technology in 4 areas: a) Biotechnology b) Nanotechnology c) Material Science Technology Energy \& Environment d) Communication and digital information technology.

6) Force and welfare are configured to motivate professionals in such professions, and work with educational institutions in teaching and research to develop new personnel and innovations in the country. 
7) Government agencies such as the Department of Skill Development set standards, the Ministry of Labor should set and adjust the guidelines for training and development, focusing on 12 new technological and innovative skills to meet the needs of the workplace's workforce.

8) Students' production of educational institutions under the Ministry of Higher Education, Science, Research and Innovation and the Ministry of Education should adjust the teaching curriculum to meet the needs of the market demand to meet the needs of the labor market sector.

9) The government should invest in opening a training center for speakers. Teachers with knowledge and expertise, including those at the center, must have equipment, advanced technology and increased access to the skills training of modern technology by providing a large and adequate number in all country regions.

10) The government should focus on the national agenda for developing and raising awareness for the country's people in technology and innovation.

11) They integrate and collaborate between the Ministry of Labor, Ministry of Higher Education, Science, Research and Innovation, Ministry of Education, and Ministry of Industry.

\section{Acknowledgements}

The author would like to thank all informants and qualified persons interviewed for information and participants in the Higher Certificate Program in Public Policy Management and Public Law. Class 18 The King Prajadhipok's Institute has been involved in coordinating information collection and compiled this article.

\section{Conflicts of Interest}

The authors declare no conflicts of interest regarding the publication of this paper.

\section{References}

Bower, J., \& Christensen, C. (1995). Disruptive Technologies: Catching the Wave. Harvard Business Review, 73, 43-53.

Christensen, C. M., \& Raynor, M. (2003). The Innovator's Solution: Creating and Sustaining Successful Growth. Harvard Business School Press.

Hollander, A., \& Mar, N. Y. (2009). Towards Achieving TVET for All: The Role of the UNESCO-UNEVOC International Centre for Technical and Vocational Education and Training. In R. Maclean, \& D. Wilson (Eds.), International Handbook of Education for the Changing World of Work (pp. 41-57). Springer. https://doi.org/10.1007/978-1-4020-5281-1 3

Hynes, N., Elwell, A. D., \& Zolkiewski, J. (2016). The Role of Inter-Organizational Networks in Enabling or Delaying Disruptive Innovation: A Case Study of mVoIP. Journal of Business \& Industrial Marketing, 31, 722-731.

https://doi.org/10.1108/JBIM-10-2012-0168 
Kaewjaroenpisan, T. (2017) Strategic Human Resources in the 4.0 S Curve Ecosystem. Journal of Public and Private Management, 24, 188-220.

Kukoyi, D. (2009). Design and Implementation of Public-Private Partnerships in Education. Case Study of Technical and Vocational Education.

Manyika, J., Chui, M., Bughin, J., Dobbs, R., Bisson, P., \& Marrs, A. (2013). Disruptive Technologies: Advances that Will Transform Life, Business, and the Global Economy. McKinsey Global Institute.

OECD (2018). Transformative Technologies and Jobs of the Future. Background Report for the Canadian G7 Innovation Ministers' Meeting. OECD.

Oviawe, J. I., Uwameiye, R., \& Uddin, P.S.O. (2017). Bridging Skill Gap to Meet Technical, Vocational Education and Training School-Workplace Collaboration in the 21st Century. International Journal of Vocational Education and Training Research, 3, 7-14. https://doi.org/10.11648/j.ijvetr.20170301.12

Prabyai, S. (2017). Century Skills Required of Technical and Vocational Education Learners in Thailand. Journal of Industrial Education, 16, 207-213.

Reeve, E. M. (2016). 21st Century Skills Needed by Students in Technical and Vocational Education and Training (TVET). Asian International Journal of Social Sciences, 16, 62-74.

Sornil, B. et al. (2005) The Route of Vocational Education and Technology. Office of the Education Council. http://backoffice.onec.go.th/uploads/Book/998-file.pdf

World Economic Forum (2016). The Future of Jobs. World Economic Forum. 